\title{
La deshonestidad de la mujer. Consejos y regulaciones en la Edad Moderna
}

\author{
The dishonesty of women. Advice and regulations in the modern age
}

\author{
FRANCISCO CARPINTERO BENÍTEZ \\ Profesor Colaborador Honorario \\ Universidad de Cádiz (España) \\ francisco.carpintero@uca.es
}

\begin{abstract}
Resumen: En los tiempos modernos, teólogos y moralistas discutieron sobre los vestidos y el maquillaje de las mujeres y su relación con la deshonestidad sexual y el pecado. Algunos autores vieron los escotes y los "afeites" como instrumentos peligrosos. Otros adoptaron una actitud más abierta y tolerante.
\end{abstract}

Abstract: In modern times, theologians and moralists discussed about women's dresses and make up and their relation with sexual dishonesty and sin. Some authors saw cleavages and afeites as dangerous instruments. Others, adopted a more open and tolerant way.

Palabras claves: deshonestidad, mujer, vestido, maquillaje.

Keywords: dishonety, woman, dress, make-up.

Sumario: 1. LA DESHONESTIDAD DE LA MUJER. CONSEJOS Y REGULACIONES EN LA EDAD MODERNA. 2. VESTIDOS Y ADORNOS DE LAS MUJERES. 3. LOS DISCREPANTES. 4. LA PÉRDIDA DE LA HONESTIDAD EN EL VESTIR. 5. CUESTIONES MÁS GENERALES. 6. CREMAS, UNGÜENTOS Y DEPILACIONES. 7. LOS ESCOTES.

\section{LA DESHONESTIDAD DE LA MUJER. CONSEJOS Y REGULACIONES EN LA EDAD MODERNA}

Puede extrañar el estudio de este tema en un filósofo del derecho. Pero, por el momento al menos, no se me ocurre otro. Sucede que llevo meses trabajando en un estudio extenso sobre la prostitución en la Edad Moderna. Y esto me ha llevado a interesarme sobre las costumbres de las mujeres de hace siglos. Por supuesto, en este artículo no me refiero a las meretrices, sino a las mujeres normales. Estimo que un estudio así añade un tono jovial a un acto necesariamente 
festivo, como es la inauguración de la Revista de nuestra Facultad. En los siglos que trato, era normal que los discursos con que los Rectores de la Universidad, al abrir el nuevo curso, tuvieran este tono, el más próximo al Gaudeamus igitur. Es cuestión de unirse a este estilo.

He preferido dejar los textos que van en castellano antiguo en su tenor literal. Posiblemente esto dificulte algo su lectura; pero añade un sabor de época que, de otra forma, perderían. Las mujeres de hoy, que trabajan, no se reconocerán en las páginas que siguen; pero deben tener en cuenta que ha cambiado mucho la condición de la mujer a lo largo, especialmente, del siglo pasado. Si quieren saber cómo vivían entonces las mujeres de las clases acomodadas, sólo tienen que leerse "La perfecta casada" de Fray Luis de León.

\section{VESTIDOS Y ADORNOS DE LAS MUJERES}

Hay cosas que hoy nos resultan muy cercanas, como es que las mujeres procuren vestir bien, que usen cremas de belleza, que se pinten las uñas o que vayan a la peluquería. Pero alcanzar esto costó tiempo y bastante esfuerzo. Las razones a favor y en contra irán apareciendo paulatinamente, que no es cuestión de soltar todo de una vez.

Tamburini se preguntaba si una mujer puede cuidar el ornato de su cuerpo sin pecado porque con ello tenía a la vista un buen fin; es decir, no usar su vestido sólo para cubrirse el cuerpo, sino atendiendo a la condición de su status social; él entiende que esto es laudable y que consona con la recta razón ${ }^{1}$.

Leonardo Lessius, uno de los teólogos que cierran la Segunda Escolástica Española -aunque él era belga-, y que fue considerado durante la Edad Moderna una de las mayores instancias para declarar la moralidad, ya había establecido que el cuidado del cuerpo (cultus corporis) es por sí indiferente, porque no va contra la caridad de Dios ${ }^{2}$. Concina representa aún una actitud intermedia entre los defensores del ornato femenino y sus detractores, porque entiende que los vestidos no han sido creados solamente para defenderse del frío y del calor, sino también para distinguirnos entre sexos y grados; de este modo, los nobles y los magistrados se visten de formas distintas a los demás hombres, y las mujeres se adornan más según que sean nobles o plebeyas, o que busquen marido o vayan a una boda ${ }^{3}$. El mismo Lessius entiende que hay que arreglar el cuerpo, y la casa, según sea la ocasión y que, en cualquier caso hay que vestir de forma congruente a la calidad de la persona, de acuerdo con las costumbres confirmadas, según los tiempos y lugares ${ }^{4}$. Puede tratarse de un lujo, ciertamente, y como todo lujo procede contra

\footnotetext{
${ }^{1}$ HUGUETAN, J. A., RAVAUD, M. A., Explicationes in Decalogum et alia opera moralia, Lugduni, 1659, p. 95

2 THEODORICI, R., De justitia et jure caeterisque virtutibus cardinalibus libri quattuor, Paris, 1610, p. 14.

${ }^{3}$ MAINARDI, Theologia christiana dogmatico-moralis elucubrata, , Roma, 1764, Tomus Prior, cap. III, titulado de Vano mulierum ornato.

${ }^{4}$ Op. cit., p. 805.
} 
la pobreza cristiana, pero si esa forma de vestir ya es costumbre social, ha dejado de ser inmoderada y es lícita usarla ${ }^{5}$.

Hubo una causa admitida por muchos para usar vestidos lujosos o atrevidos, y fue el de la mujer casada que dice que quiere agradar a su marido. Tamburini entiende que si es así realmente, esto es laudable ${ }^{6}$, y lo mismo opina Lessius ${ }^{7}$. El problema se planteaba porque si el vestido había de ser libidinoso para agradar al marido, la esposa únicamente lo podía usar dentro de su casa $^{8}$.

Los vestidos bellos no eran privilegio de las mujeres nobles o de las casadas. Porque era lógico tener en cuenta que las que querían casarse deseaban presentar un aspecto atractivo, de modo que agradaran a los hombres y pudieran conseguir unas commodas nuptias ${ }^{9}$. Tamburini entendía que incluso las mujeres solteras y que no deseaban contraer matrimonio, podían vestirse elegantemente, no para ser deseadas torpemente por algunos hombres, sino para que pudieran ser incluidas en el censo de las mujeres bellas y fueran alabadas como tales ${ }^{10}$.

Tomás de Aquino y los que seguían su estilo, poseían un espíritu más abierto. Lessius, citando al de Aquino, explicaba que las mujeres ya casadas, o las que aspiraban a estarlo, podían cuidar el ornato para su belleza. De hecho, Santo Tomás había explicado que la mujer puede lícitamente adornarse bien para conservar la decencia correspondiente a su status, o bien para agradar a los hombres ${ }^{11}$. Balduino miraba más directamente a Dios y explica que no hay que creer que sea pecado llevar un 'espléndido vestido', porque Dios no se preocupa por los vestidos; pero, en honor a Dios, hay que llevar el cuerpo elegantemente ${ }^{12}$. No le agradaba a Balduinus la fatuidad y lo superfluo, pero tampoco ir vestida indecorosamente ${ }^{13}$. Tampoco quería la soberbia inherente a la que iba cargada de oro, plata y piedras preciosas ${ }^{14}$.

Pero las actitudes se radicalizaron con el paso del tiempo. Celada echaba de menos los tiempos de Clemente Alejandrino, que escribía "Admiro la ciudad de los Lacedemonios, en las que sólo estaban permitidos los vestidos floridos y el oro a las meretrices" porque, según él mismo, los vestidos pretiosi prostituyen, y la frugalidad en el vestido es un apéndice de la castidad ${ }^{15}$. "Por

\footnotetext{
${ }^{5}$ ALBERTIS, Paradoxa Moralia de Ornatu Mulierum, Ludovicus Montia, 1650 NOTAX. CIUDAD. p. 11.

${ }^{6}$ Op. cit., p. 95.

${ }^{7}$ Op. cit., p. 805.

${ }^{8}$ EZCARAY, Vozes del dolor nacidas de la multitud de pecados, que se cometen por los trages profanos, afeytes, escotados y culpables ornatos, López de Haro, Sevilla, p. 71.

${ }^{9}$ LESSIUS, op. cit., p. 805.

${ }^{10}$ Op. cit., p. 95.

${ }^{11}$ Así, LESSIUS, op. cit., p. 805.

12 WACHTLER, G., De casibus conscientiae, Impensis, Francofurti, 1654, p. 646.

13 Op. cit., pp. 646-647.

${ }^{14}$ Op. cit., p. 647.

${ }^{15}$ Judith illustris perpetuo commentario literali, et morali, Ex Typographia Regia, Madrid, 1641, p. 9, parágrafo
} 
esto, la ambición en los vestidos deviene un adorno de la petulancia, de modo que las mujeres (con vestidos textiles) se prostituyen ante los ojos de los que las ven, porque vistiéndose no se cubren, sino que se desnudan vistiéndose, a lo que les lleva el ingenio de lo libidinoso"16. Denosta contra los vestidos insinuantes, en los que las mujeres, cuando más se ponen, más enseñan ${ }^{17}$. Compara a las mujeres que se arreglan con las vírgenes necias del Evangelio ${ }^{18}, \mathrm{y}$ entiende que estas mujeres cumplen la misma función que la Gran Tentadora, nuestra madre $\mathrm{Eva}^{19}$.

\section{LOS DISCREPANTES}

Francisco Pérez de Prado, Obispo de Teruel, tronó fuertemente contra las modas nuevas. Él explica que muchos teólogos solían considerar las cosas in se, oformaliter, o metafisicamente, de modo que una conducta in se et per se no era mala moralmente, pero considerada en la práctica sí que lo era. Él, para despejar dudas acerca de lo que habla, indica que no quiere tratar estos temas methaphysice o praecisive, "Que de essa suerte ni la Comedia, ni el Bayle es malo". Él quiere tratarlos tal como son en realidad, legislative, esto es, en el conjunto de sus circunstancias, tal como los realizan los individuos concretos ${ }^{20}$.

Según él, si queremos saber cómo ha de vestir una mujer, tenemos el retrato de Isabel la Católica, en la que su vestido cubría los pies, brazos, pechos y cuello. Después vino el escotado, desnudando el hombro, "Y sin embargo de haber declarado el Rey este trage por meretricio ... halló defensores entre Christianos el desnudarlos y verlos. Cubriose el ombro y se desnudaron los pechos, brazos y calçado; y tiene tambien esto sus defensores que se nos citan contrarios" ${ }^{21}$.

Prosigue: "Esto es el trage y adorno profano ... Dezimos sobre el primero: Que el trage y adorno gravemente superfluo, sumptuoso, cuidadoso, provocativo, y desnudo, aunque se vista sin intención de provocar a la liviandad, es pecado mortal, que ni le puede mandar el marido, ni traer la muger, ni autorizar el Principe ${ }^{22}$. "El trage precioso, y desnudez de las mugeres nuda pectora, et mamillas, si absit provocationis intentio, (si falta la intención de provocar enseñando los pechos) no es pecado grave y aun oye licitud en el mismo curso citado, punto I (ignoro a qué curso, libro o apuntes se refiere) Si ut placeant maritis, et ita ferant patrii mores ("Si así agradan a sus maridos y es costumbre en su patria"). "Y sin embargo por el auto acordado por el Consejo con asenso real del 13 de abril de 1639, inserto al fin del tit. 12, lib. 23 Recop. se

IV.

${ }^{16}$ Op. cit., p. 10.

${ }^{17}$ Op. cit., p. 10.

${ }^{18}$ Op. cit., p. 8.

${ }^{19}$ Op. cit., p. 11.

${ }^{20}$ Defensa canonica de la potestad decretoria, y executiva que por el derecho de Jesu Christo y de su Iglesia tienen los obispos sobre sus subditos legos en las causas del foro eclesiástico. No constan editor ni lugar, 1734.

${ }^{21}$ Op. cit., p. 583.

${ }^{22}$ Op. cit., p. 581. 
mandó que "Ninguna muger pueda traer jubón escotado, salvo las que públicamente ganan con sus cuerpos, las quales lo pueden traer con el pecho descubierto; y a todas las demás se los prohíbe" 23 . Pero, ¡Hay de nuestros tiempos! Estos trajes son frecuentes, y las mujeres se corrompen $^{24}$. Pero dejemos aquí la retahíla de condenas que expone Pérez de Prado, que su libro tiene ochocientas páginas, y casi todas ellas debieran ser citadas por el que quiera exponer los pretendidos abusos de las mujeres en el siglo XVIII.

Las predicaciones de los teólogos eran rechazadas con frecuencia, porque todos tenían unas ciertas nociones del 'probabilismo moral', y Ezcaray, desde sus vivencias en España y en México, nos cuenta que "Hablo de experiencia, porque en diziendoles: "Quítese eso, señora", me responde: "Padre, ya sabe que yo no peco, yo no me pongo con el fin de que me enamoren los hombres" 25 . Y añade: "Si el Padre dize que es profano, yo digo, que no lo es, y no tiene más autoridad el Padre, que yo para dezirlo, que si él tiene Autores, yo también; y como ni su dicho, ni el mio, son Canon conciliar, cada uno seguirá lo que quisiere"26. (El probabilismo es la teoría moral que entiende que, si yo tengo 'buenas razones' para hacer u omitir, puedo actuar tal como pienso, aunque la mayor parte de las autoridades en la ciencia moral entiendan que esa conducta no es lícita. No está claro quién fue el primero que mantuvo esta teoría. Algunos dicen que fue Antonio Escobar y Mendoza, jesuita, a comienzos del siglo XVII ${ }^{27}$. Otros la retraen a españoles del siglo anterior).

El caballo de batalla era la profanidad. Ezcaray, otra vez, nos indica que "Pues, si esto dice este Padre Maestro, y lo antecedente a dicho el Reverendissimo Lumbier, ¿qué mucho diga yo, es muy dificultoso señalar qual es la profanidad y qual no? Y por esto lo dejo a la prudencia del Confessor docto, y experimentado, que consideradas bien las circunstancias, y todo lo que se deba considerar, resolverá, según Dios, lo que más convenga"28.

Tenían presente la primitiva forma cristiana de vestir, concretamente lo que vestía Cristo, y condenaban los excesos sobre los vestidos evangélicos ${ }^{29}$. Pues los fines del vestido son tres: cubrir la desnudez, defenderse del frío y la honesta compañía ${ }^{30}$. Este autor añadía que "Para que veias la superfluidad con que andáis algunas, notad: no os contentais con traer el pelo y cabeza llena de cintas, y rosas, sino que añadis a la frente un trapo, que llamais chiqueador. Y

\footnotetext{
${ }^{23}$ Op. cit., p. 542.

${ }^{24}$ Op. cit., p. 796.

25 Op. cit., p. 49.

${ }^{26}$ Op. cit., p. 60.

${ }^{27}$ ESCOBAR y MENDOZA, Examen y practica de Confessores y penitentes en todas las materias de la Theulogia

$<$ sic $>$ moral, Juan de Lanaja y Quartaner, Zaragoça, 1635. La primera edición de esta obra fue en 1620.

${ }^{28}$ Op. cit., p. 58.

${ }^{29}$ BALDUINUS, F., Tractatus de casibus conscientiae, Impensis Caspar Wachtler, Francofurti, 1654, p. 647.

${ }^{30}$ Op. cit., p. 86.
} 
si dezis, que es por dolor de cabeza, ¿para que se borda con hilo de oro, seda y lentejuelas? ${ }^{31}$. (Al referirse a esta última prenda, el chiqueador, parece estar escribiendo más para México).

Pero la enumeración expuesta hasta ahora por Ezcaray es pobre, porque en otros momentos escribe: "Quitadles zapatos, medias, ligas, brazaletes, las medias lunas de plata, collares, pulseras, cadenas de oro, brazaletes, moños enrizados, trençados, todo el pelo, arrancados, guantes, pomas, abujetas de olor, tirantes, cabestrillos, anillos, diamantes, perlas, aljófar, rubies, cabelleras postizas, mantos claros, tocas de Reyna, abujas de plata, alfileres, espejuelos, cintas, colonias, estufas, etc." 32 . Esta profanidad "La veo introducida por todas partes ... en nuevas invenciones y formas en los trages"33. Escandalizado, escribe: “¿Que mas perdición, que ponerse zapatos de una oreja, como los hombres, y en lugar de cintas un botón? ... ¿Qué mayor irritación a la torpeza, que hacer los zapatos de cuerecillo de ambar, y ponerles viriles de plata sobre las suelas?"34.

Según él, ni mujeres ni hombres visten honestamente. "La muger, las sayas abiertas, que al andar dan el pie a las sayas para que por la abertura se vea la otra saya y el forro de la que va abierta”. En cuanto a los hombres, “¿Qué mas incentivo de luxuria, que ver a los hombres con unos calçones tan ajustados, que en la misma estrechez manifiestan la forma del muslo, y algo más que por decencia callo, y parecen una pieza el hombre, y los calçones ${ }^{35}$. Sicardo nos decía que "El Padre Laínez, Varón Apostólico, de la Compañía de Jesús, referido en el libro impresso en Santiago contra los abusos de los escotados, fol. 79. dice que algunas mugeres ponen tanto estudio y afecto en adornarse, que parece que adoran por su Dios a su cuerpo, porque le sacrifican el ingenio, la memoria, la voluntad, la lengua, los trabajos, y toda su substancia; pues no piensan, no se acuerdan, no hablan, no trabajan, ni estudian, sino en como se han de componer, y dan en adorar este ídolo a otros, andando pomposamente por las calles, plazas y Templos" ${ }^{\prime 3}$.

Concinna, desde fuera de España, exponía un discurso parecido: la malicia de este ornato no viene tanto de lo superfluo y del precio excesivo, como de la inmodesta forma de toda esta ornamenta. Un vestido precioso puede ser elegante, y de gran precio y, al mismo tiempo, ser púdico y verecundo, como sucede con las matronas nobles y las esposas de los príncipes. Pero, por lo general, los vestidos de estas mujeres son vanos, deshonestos, impúdicos, que hacen soberbias a las mujeres y les quitan el pudor. ¡Hay de los confesores que admiten a los sacramentos de Cristo a estas matroncillas teatrales ya sin pudor! ${ }^{37}$. (Hace una referencia al

\footnotetext{
${ }^{31}$ Op. cit., pp. 27-28.

32 Op. cit., p. 60.

${ }^{33}$ Op. cit., p. 61.

${ }^{34}$ Op. cit., p. 21.

35 Op. cit., pp. 18-19.

${ }^{36}$ SANZ, F., Judizio Theologico moral, que haze de las galas, escotados y afeytados de las mugeres, Madrid, $2^{\mathrm{a}}$ ed., 1677, p. 61 .

${ }^{37}$ Op. cit., p. 88.
} 
teatro porque a las compañías teatrales las seguían un grupo de prostitutas, de ciudad en ciudad, desde los tiempos de Roma, y una forma de tildar de prostituta a una mujer era llamarla mulier scaenica. Los actores o hystriones no tenían mejor fama).

Estas mujeres no buscan sólo la belleza. Ignatius echaba mano del Satírico (Plauto) para expresar que "Rara es la concordia de la forma y del pudor", porque así como es molestísimo poseer lo que todos odian, igual de difícil es tener lo que todos apetecen ${ }^{38}$. De la Haye indicaba que "El deseo de los vestidos preciosos denota la debilidad máxima": Pretiosa vestis appetitus infirmitas maxima ${ }^{39}$. Y era más rotundo cuando, en este mismo lugar, declaraba que Vestimenti pretiosi diabolus inventor.

\section{LA PÉRDIDA DE LA HONESTIDAD EN EL VESTIR}

Como suele suceder en muchos casos, la decadencia se atribuía, en buena medida, a las costumbres de las mujeres, normalmente a sus vestidos indecentes. Azpilcueta enseñaba que "Quien pueda, está obligado a ir decentemente, de acuerdo con su estado. Quien vive indecentemente, peca, como lo indica el capítulo canónico Quia contra mores... Leemos en Santo Tomás que "Todos están obligados a presentarse ante sus prójimos de una forma delectable" 40 .

Y éste no es tema baladí, porque Concina enseñaba, en su pretendido magisterio, que el pudor de una mujer resulta en su vestido, y también se remitía a Santo Tomás, en el cap. 2 al Comentario al Evangelio de San Juan: "Lo que arde en la mente luce en el vestido y se irradia por la boca" ". Era un tema viejo, porque ya Séneca había dejado escrito que "Veo vestidos de seda, si se los puede llamar vestidos, porque en ellos no hay nada que proteja al cuerpo o que guarde el pudor" ${ }^{42}$. Azpilcueta era de la opinión que, mejor que llevar oro y sedas, es hacer limosnas ${ }^{43}$.

\section{CUESTIONES MÁS GENERALES}

La lujuria está siempre próxima, por su connaturalità y su domesticità ${ }^{44}$. El autor de esta frase, Giustinelli, nos dice que la impudicia nos trae nausea, porque es un desprecio de Dios y de su

\footnotetext{
${ }^{38}$ JOSEPHUS IGNATIUS, D., Jura mulierum ex Jure Canonico, Civile, Feudali, Bohemio, et Moravico, Johannes Wenceslaus Helm, Praga, 1718, parágrafo V

${ }^{39}$ PETIT PAS, J., y BILLAINE, P., Arbor Vitae concionatorum in Genesim, , París, 1633, p. 469.

${ }^{40}$ Opera omnia in sex tomos distincta, Yuntas, Venetiis, 1602, Tomo 3, p. 602-Dorso.

${ }^{41}$ Op. cit., p. 9

${ }^{42}$ CELADA, op. cit., p. 10.

${ }^{43}$ OPERA., op.cit., Tomo 3, cit., p. 602.

${ }^{44}$ GIUSTINELLI, Trionfo della castità contra il vitio dell'incontinenza, Giacomo Mascardi, Roma, 1614, p. 9
} 
salvación ${ }^{45} \mathrm{y}$, por el contrario, la castidad nos lleva hacia la belleza ${ }^{46}$. Es tema delicado, porque tanto afecta a los viciosos como a los virtuosos ${ }^{47}$. Lessius hace notar que desde la lujuria nacen otros vicios ${ }^{48}$. Seguir la doctrina de las opiniones probables lo confunde todo, porque según Gavarri "Hazerla, virtualmente está diciendo: Ora sea esto pecado mortal, ora no; ora la prohíba Dios, ora no la prohíba, yo tengo que hazerlo"49

\section{a) Tonos menores}

Alberto de Albertis, S.J., conocido por su criterio rígido en los temas que hacen al sexo, explicaba, a pesar de su rigidez, que si las mujeres llevan vestidos elegantes, "Si esto lo hacen por una cierta frivolidad (ex levitate animi) y vanidad, para mostrar la belleza y elegancia de su cuerpo, sólo pecan venialmente" ${ }^{50}$. Sucede, prosigue Albertis, que la mujer es por sí misma provocativa, porque ésta es su condición natural, y tiende a promover la concupiscencia. Ella no tiene la culpa de su belleza, pero si exhibe esta belleza para provocar, entonces sí comete pecado $^{51}$. Torrecilla trata el ornato de la mujer y explica que "Siguese que la muger no peca en adornarse según la costumbre de la patria, aunque sepa que por tal ornato ha de ser amada lascivamente de alguno, porque en esto usa de su derecho. Imo, ni pecara a lo menos mortalmente, aunque el adorno sea superfluo, y máximo, y aunque prevea, que por ello ha de ser deseada torpemente de algunos, con tal que no lo haga con intención de provocar a libido ... pero lo contrario, dizen, si fuesse habito, y vestuario peculiar de las meretrices" ${ }^{\prime 2}$.

Cornelius Cornelii a Lapide situaba el fundamento del problema: "Nosotros hemos sido creados por Dios para la felicidad eterna, redimidos por la sangre de Cristo, similares a la Trinidad Santísima, adornados por don de la gracia, y casa y templo del Espíritu Santo, y el diablo trata de llevarnos a la gehena"53. ¿Qué es el escándalo, se preguntaba Concina? "Es el dicho o hecho menos recto que nos pone en camino a la ruina espiritual. Bajo el nombre de dicho o hecho se comprende también la omisión" 54 .

Efectivamente, desde el trato con las mujeres puede provenir el escándalo, lo que no implica que hayamos de huir de ellas. Tamburini, siempre más comprensivo con las flaquezas nuestras, indicaba que "Mirar la cara de una mujer, sus manos y sus brazos, su pecho, en suma, sus partes

${ }^{45}$ GIUSTINELLI, op. cit., p. 152.

46 Op. cit., pp. 365 y ss.

${ }^{47}$ Op. cit., p. 4.

${ }^{48}$ Op. cit., p. 757.

${ }^{49}$ FERRER, A., y FERRER, B., Noticias singularissimas de las preguntas necessarias que deven hacer los PP. Confesores, Barcelona, 1677, p. 199-Dorso.

${ }^{50}$ ALBERTO DE ALBERTIS, op. cit., p. 13.

${ }^{51}$ Op. cit., p. 133.

${ }^{52}$ Op. cit., p. 250.

${ }^{53}$ HIERONYMUS ALBRITI, H., Commentarius in Salomonis Proverbia, Venetiis, 1717, p. 107.

${ }^{54}$ Op. cit., p. 81. 
honestas, esto no es por sí pecado; que si se hace por la delectación que se sigue de la simple visión, de ese tipo de delectaciones que no llamamos libidinosas, no es siquiera pecado mortal" ${ }^{55}$. Aunque Tamburini nos advierte que no siempre es culpable la mujer, porque no pueden estar siempre limitadas cuando el prójimo es pura malicia y abusa de la visión para el pecado: entonces se da el escándalo pasivo, que llaman farisaico, que no tienen la obligación de evitar ${ }^{56}$.

Hay teólogos que van predicando que, en temas de sexo, no existe 'parvedad de materia', es decir, que si realmente se comete pecado contra la castidad, este pecado es siempre grave. Por contra, Diana, el gran casuista, explicaba "Que en materia de lujuria se da parvidad $<$ sic $>$ de materia, afirma Salas, Marchando, y con algún miedo Lessio, porque la delectación venera, de sola la vista muchas veces no es pecado mortal ... mientras no se juntare con ardor grande de concupiscencia" ${ }^{57}$. La mujer que está desnuda en el estudio del pintor, explica Tamburini, o que se desnuda por juego, o por curiosidad de la narración, o por la suavidad de la poesía, no comete pecado mortal" 58 . Torrecilla explicaba que sí existe en estos temas 'parvedad de materia', sea cuando la voluntad consiente perfectamente en cosa leve, o cuando consienta imperfectamente en cosa grave ${ }^{59}$. Se puede saber "si la cosa" es grave o leve según la proximidad del varón a la polución (pollutio) o cópula, porque si la inclinación a esas cosas es pequeña, o no hubiere peligro, será pecado venial. Y fundamenta esta opinión en una enumeración interminable de doctores $^{60}$. Sucede que, por el trato con las mujeres, algunos tienen una polución; pero si esta polución no se busca, ni hay peligro de consentir en ella, la conversatio con las mugeres no tiene por qué acabar" ${ }^{61}$. Torrecilla describe a la polución como "Voluntaria seminis emissio absque copula" ${ }^{\prime 2}$.

El tema de la 'parvedad de materia' puede ser malentendido en estos autores. Ellos distinguían tres tipos de placer sexual: el natural, el libidinoso y un tercero que nunca he entendido bien en qué consiste. Diana explica que "No aparece la razón por la que la no pueda haber levedad de la materia frente al pecado mortal, cuando la materia es pequeña ... Cuando el inicio $<$ del juego, de la conversación, de los besos, etc.> es tan pequeño que no puede hablarse de pecado mortal, de forma física, según la sustancia de la virtud, sino que sólo una disposición remota e imperfecta, no será tal inicio pecado mortal, aunque el acto sea mortal"63. Parece que, según Diana, todo depende de la proximidad o lejanía a la eyaculación o al coito. Torrecilla es más

\footnotetext{
55 Op. cit., p. 93.

56 Op. cit., p. 19.

${ }^{57}$ Suma Diana, recopilado en romance todos los once tomos del R. P. D. Antonino Diana, Madrid, 1657, p. 512.

58 SÁNCHEZ, M., Explicationes in Decalogum et alia opera moralia, Joannes-Antonius Huguetan et MarcusAntonius Ravard, Lugduni, 1659, p. 93.

${ }^{59}$ Op. cit., p. 604.

${ }^{60}$ Op. cit., p. 603

${ }^{61}$ SÁNCHEZ, J., Disputationes de sancto Matrimonii Sacramenti, Yuntas, Venecia, 1725, p. 53.

${ }^{62}$ Op. cit., p. 583.

${ }^{63}$ Op. cit. Tomo 7, Tract. II, p. 30.
} 
rotundo: "Yo empero soy del sentir: que cualquiera delectación venerea, por pequeña que sea, si consiente la voluntad en ella, positive, expresse et formaliter, será pecado mortal: porque en materias venereas, no admito parvidad de materia, moraliter et practica, por razón del peligro anexo" $"$ ¿Cómo conciliar ambas declaraciones en autores que tan frecuentemente muestran estar tan próximos? Parece que el peso del problema recae en la intención: si el hombre quiere llegar hasta la eyaculación o el coito, aunque la parvedad de las relaciones no lo permita, hay voluntad de pecar en tema grave. Lessius no duda en afirmar que el uso venéreo, fuera del matrimonio, es pecado grave ${ }^{65}$. Parece confirmar esta opinión Tamburini cuando dice que si en las cosas venéreas no se da parvedad en orden al coito o a la generación, siempre eo ipso, ya que es venérea, hay un inicio de la cópula o de la polución ${ }^{66}$. Este mismo autor vuelve a explicar que si la delectación que surge desde la visión de una mujer bella, o del contacto con sus manos sin que exista peligro más allá, no es delectación en cosa venérea ${ }^{67}$. Lo venéreo o libidinoso parecía reservado a lo que lleva a los actos propios de la generación: el simple placer que no lleva hacia esos actos, no es pecado grave.

Cornelius a Lapide, siempre más rigorista, indica que los Padres de la Iglesia enseñan que la familiaridad, el coloquio con las mujeres, el simple tacto, es adulterio ${ }^{68}$. Aunque también puede entenderse este texto como que estas cosas no constituyen ya el adulterio, pero predisponen a él. Aunque también puede entenderse en el primer sentido indicado, porque él indica que la misma familiaridad con las mujeres, y contactos leves, aunque sólo sea en el aspecto, las bromas y risas con ellas, convierten en infamia la fama de los que conversan, porque nacen en el alma varias concupiscencias deleitosas, aunque no se adviertan, que llevan hacia la fornicación y el adulterio ${ }^{69}$.

Algunos estaban escandalizados por las conversaciones demasiado frívolas entre mujeres y hombres. Según Concina no hablan de temas civiles, honestos y necesarios, sino de cosas muy corrompidas $^{70}$. Esto puede deberse, según este autor, a que las mujeres, por la ambición y vanidad que llevan en ellas, captan y anhelan los regalos y al servidumbre de los hombres, por no decir su adoración ${ }^{71}$.

En el estilo revuelto que a veces usa este castellano primitivo, y que tan especialmente patente es en Santa Teresa de Jesús (ella era consciente de que redactaba mal), Torrecilla sigue indicando que "Juan Sánchez ... dize, pues que cuando el hombre siente, que la delectación le turba la razón, y que no le da lugar para pensar otras cosas fuera de las carnales: y si las tales

\footnotetext{
${ }^{64}$ Op. cit., p. 603.

${ }^{65}$ Op. cit., p. 756.

${ }^{66}$ Op. cit., p. 92.

${ }^{67}$ Op. cit., p. 92.

${ }^{68}$ Op. cit., p. 107.

${ }^{69}$ Op. cit., p. 107.

${ }^{70}$ Op. cit., p. 188.

${ }^{71}$ Op. cit., p. 188.
} 
circunstancias faltaren, se ha de tener por pequeña y leve"72. Solamente los herejes entienden que los movimientos que suscita el sexo primo primi, constituyen pecado mortal ${ }^{73}$. (Juan Sánchez fue un moralista que redactó el tratado sobre el matrimonio más tenido en cuenta a lo largo de este tiempo).

Algunos autores entienden que los movimientos que suscita el sexo son muy naturales porque la fornicación simple (la que no es adulterio o de persona con voto de castidad) está prohibida por la ley divina, no por la ley natura ${ }^{74}$. ¿Qué decir de las personas sin instrucción, rustici seu vulgares, en este tema? Azor entiende que si la ignorancia es invencible, esta fornicación no es pecado; aunque reconoce que hay otros doctores que estiman que en este caso no existe ignorancia invencible ${ }^{75}$. Algunos entienden, siguiendo la mayor facilidad, que se puede ignorar que la fornicación con las meretrices no es pecado mayor que el que se comete con una mujer lujuriosa; hay muchos hombres vulgares que no saben distinguir entre los pecados permitidos y no permitidos en lo que hace a la pena y no a la culpa, y porque no se castiga la simplex fornicatio, sino que se permite trabajar libremente a las meretrices, entienden que no es pecado acceder a ellas ${ }^{76}$.

Torrecilla parece aludir a las masturbación de la mujer cuando escribe que "La donzella es dueña del uso de ese miembro, como del uso de los demás, y que la tal abcission (¿?) seria parvidad de materia; y assi podría no ser grave culpa contra el precepto de guardar la integridad de su cuerpo" 77 . Azor se refiere a la pollutio mulieris ${ }^{78}$, sin especificar más.

Existen algunos casos algo especiales. Uno es el del padre que no casa a su hija, de modo que llega soltera a los veinticinco años ${ }^{79}$; ese padre no podrá quejarse si esta hija actúa poco honestamente. Si un padre tiene una hija hermosa y bien educada, y la sitúa en matrimonio con un varón honesto, habrá de darle de dote trescientos aureos; pero si esa hija ha corrompido ya a algunos escolares, la dote habrá de ser de mil aureos ${ }^{80}$. Advierto desde ahora que en estos siglos los protagonistas de la prostitución eran las mujeres profesionales y los estudiantes, los scholares, como si los demás hombres no tuviesen participación en este oficio. Porque por los ejemplos que van proponiendo sobre, por ejemplo, quien es una prostituta oculta, los escolares llevan el protagonismo.

\footnotetext{
72 Op. cit., p. 603.

73 TORRECILLA, op. cit., p. 597.

${ }^{74}$ AZOR, op. cit., columna 177.

75 Op. cit., columna 177.

${ }^{76}$ BABA, F., Resolutiones morales in sex partes distributae, Venetiis, 1698, T. 8, p. 676.

77 Op. cit., p. 533.

${ }^{78}$ Op. cit., col. 174-175.

${ }^{79}$ GEORG, J., Kees, Commentarius ad D. Justiniani Institutionum Imperalium, Johann Andrea de la Haye, Ingolstadt, 1738, p. 317.

${ }^{80}$ BERLICHIO, M., Quinta Pars Conclussionum Practicabilium secundum Ordinem Constitutionum divi Augusti, Johann Andrea Mintzelius, Lipsiae, 1628, cap. 37, nº 13.
} 
Azpilcueta previene frente al confesor imprudente que impone una penitencia, si el que se confiesa es un melancholico, y esto le lleva a la desesperación, es decir, al aumento de la melancolía y de la tristeza, porque le impone tal o cual tiempo de ayuno, o por evitar el buen trato con personas honestas o con algunas recreaciones ${ }^{81}$.

\section{b) Tonos mayores}

Según Torrecilla, "Los que pintan cosas torpes, como Venus o Adonis, descubiertas las partes pudendas, o cubiertas con algún velo diáfano, pecan mortalmente con pecado de escándalo, porque estas cosas provocan grandemente a la lujuria"82. "Y lo mismo debe decirse de los que escriben libros torpes y llenos de lascivia, que provocan a cosas venéreas" ${ }^{83}$. ¿Es lícito que los pintores reproduzcan imágenes torpes?, preguntaba Concina. Esto lo niegan absolutamente todos, y no conocemos las reglas exactas para definir cuando una pintura es obscena. Lo cierto es que crean cuadros con imágenes femeninas que muestran con vivos colores los rostros y los pechos de las mujeres, cosas que, por su propia naturaleza, incitan a lo venéreo. Estamos ante un tema de prudencia cristiana, concluye este autor ${ }^{84}$.

Concina se centra, otra vez, en las conversaciones y cantinelas. Los jóvenes usan palabras propias del lenocinio, metáforas y alegorías que son injuriosas y que ridiculizan, sacadas de los libros obscenos que llaman Romanzi, escritos por poetas impúdicos, que hoy tiene en sus manos cualquier mujercilla ${ }^{85}$.

La lujuria hace daño al honor y a la fama en todo tipo de personas, especialmente a las mujeres ${ }^{86}$. Y vuelve a la mente incapaz para la consideración de las cosas espirituales, y despojadas estas mentes de su dignidad, caen en una caecitatis mentis, en una ceguera de la razón ${ }^{87}$. Si una mujer casada se da a la mala vida contrae la nota de infamia y pierde el nombre honorífico de matrisfamilias ${ }^{88}$.

Aparecen, hablando en general, como es ahora el caso, algunos problemas menos usuales en estas fuentes. Existen algunas personas casadas que se acusan de que, habiendo tenido ya la copula, y pasadas las palabras de amor, han hablado con sus esposas, de temas impúdicos; esto, escribe Diana, no es pecado, porque pertenecen a la honestidad del matrimonio y a la honestidad del coito ${ }^{89}$. Otros casados se acusan de sodomía con su mujer, y hay que decirles que esta cópula

\footnotetext{
${ }^{81}$ Op. cit., Tomo 3, p. 269-Dorso.

${ }^{82}$ Op. cit., p. 251.

${ }^{83}$ Op. cit., p. 251.

${ }^{84}$ Op. cit., p. 91.

${ }^{85}$ Op. cit., p. 81.

${ }^{86}$ GIUSTINELLI, op. cit., p. 305. Sobre las mujeres, vid. p. 310.

${ }^{87}$ LESSIUS, op. cit., p. 757.

${ }^{88}$ HAMMERER, Dissertatio inauguralis de quaestu meretricio, Franciscus Le Roux, Argentinae, 1744 , p. 7.

${ }^{89}$ Op. cit., T. 1 , p. 220.
} 
del varón con el vaso posterior de la mujer no es propiamente sodomía; porque en la sodomía no se peca sólo contra el vaso, sino contra el sexo, y el varón que actúa así con su esposa, aunque no respete el vaso sí respeta al $\operatorname{sexo}^{90}$. A tenor de la frecuencia con que Diana y Torrecilla tocan este tema, parece que era relativamente frecuente entre los matrimonios. Otro tema corriente era el de saber quién peca más en las relaciones ilícitas, si el varón o la mujer. Sayro explica que por lo general peca más el varón porque tiene más razón que la mujer; pero esto hay que entenderlo sólo de la simple fornicación, porque en el adulterio peca más la mujer por el daño que origina con sus hijos adulterinos ${ }^{91}$.

Diana entiende que el confesor debe preguntar a la penitente de forma delicada, suavi et humano, para que este sacramento no se le vuelva más costoso ${ }^{92}$. El señor De la Haye explica que la ley se impone según las personas ${ }^{93}$, y que Dios siempre castiga benignamente al hombre ${ }^{94}$. Sucede, en definitiva, que Diabolus maxime nobis inferior ${ }^{95}$.

Después de estas pinceladas, parece el momento de pasar a cuestiones más concretas, que se puede entender que en parte han sido tratadas ya, y también que son sólo un aperitivo para que el estómago del lector pueda ir haciendo la digestión de unos temas que por su domesticità e naturalità, como decía Giustinelli, son pan de todos los días. Comencemos por el uso de las cremas de belleza y de las depilaciones.

\section{CREMAS, UNGÜENTOS Y DEPILACIONES}

La mujer europea, durante muchos siglos, solía ir vestida de arriba abajo, bien con la cabeza tapada en su parte superior, bien con un sencillo peinado. Así solían describirlas los hombres de la Edad Moderna que se horrorizaban de la liviandad de los vestidos de las mujeres a partir del siglo XVII. Y se escandalizan, quizá más que por los vestidos, por las cremas que cubrían sus caras.

La moralidad en el uso de las cremas de belleza estuvo determinada durante mucho tiempo, por los escritos de los Padres de la Iglesia. Ellos, que vivieron en los tiempos del Bajo Imperio, asistieron al espectáculo de unas mujeres romanas que una forma bastante manierista, abusaban del uso de tales cremas, de las joyas y de los vestidos. Las opiniones sobre la licitud de su uso estuvieron determinadas, durante bastante tiempo, por lo que Tomás de Aquino había dejado escrito sobre ellas, aunque ya sabemos que las opiniones del de Aquino y de los tomistas solía ser bastante más benigna, por realista, que las de otros moralistas.

\footnotetext{
${ }^{90}$ DIANA, op. cit., T. 1, p. 304.

${ }^{91}$ Compendii Clavis Regiae. Pars Secunda, Joannes Baptista Ciottum, Venetiis, 1621, p. 478.

92 Op. cit., p. T. 1, p. 171.

93 “Lex imponitur secundum personarum ratione". op. cit., p. 350.

${ }^{94}$ Op. cit., p. 345.

${ }^{95}$ Op. cit., p. 333.
} 
Concretamente, Tomás había entendido que las cremas de las mujeres crean una cierta ficción, que no puede ser sin pecado. Por lo que San Agustín había explicado que los fucos que hacen a las mujeres más rubias o más pálidas, constituyen una falacia adulterina con la que eran engañados sus mismos maridos, quienes pueden permitir, no ordenar, a sus mujeres que las usen $^{96}$. Pero no siempre tal fucatio es pecado mortal, sino sólo cuando se hace por lascivia o por desprecio a Dios, porque una cosa es fingir una belleza que no se tiene, y otra tratar de ocultar algún defecto hecho por una enfermedad o por otro motivo; esto último es lícito ${ }^{97}$.

El escándalo venía dado porque Judith, la heroína del pueblo Hebreo, se había adornado, y Celada, que en su rigor tradicionalista no estaba dispuesto a dar su brazo a torcer, explicó que Dios le había dado belleza del cuerpo y una extraordinaria dignidad en la cara ${ }^{98}$. Este autor ya había explicado que esas mujeres, que van cambiando de cara, de peinado, de vestido, que no faltan a las fiestas importantes, que se dedicaban a las festividades lascivas y libidinosas, más parecidas a la belleza de los sepulcros; y que esto es lo que sucede con las mujeres que se pintan la cara ${ }^{99}$. Se engañan a sí mismas porque caen bajo las mentiras de los espejos y son infieles a su cara ${ }^{100}$. Él concluye, en su defensa de la moral, que las cremas en la cara son incentivo de la libido y meditación sobre el adulterio ${ }^{101}$. Beverland denunciaba que las mujeres se pasaban el día entre el espejo y la peineta ${ }^{102}$.

Este problema también se enmarcaba en el del lujo de las mujeres al vestirse: "El lujo en los vestidos es la fuente y origen de muchos males, excitan hacia otros pensamientos depravados, impiden la misericordia: son un signo de la soberbia del alma"103. Alberto de Albertis indicaba que si no tienen ninguna necesidad o utilidad para hacer esto, sino que estas mujeres son llevadas por la sola vanidad, serán vistas torpemente por sus admiradores, y pecan mortalmente ${ }^{104}$. Concina recurría a fuentes bíblicas: “¿Acaso el boato de las mujeres no está reprobado por la Escritura Santa? Los profetas se pronunciaron vehemente y acérrimamente

\footnotetext{
96 "Ad secundum dicendum quod mulierum fucatio, de qua cyprianus loquitur, est quaedam species fictionis, quae non potest esse sine peccato. Unde Augustinus dicit, in epistola ad possidium, fucari figmentis, quo rubicundior vel candidior appareat, adulterina fallacia est, qua non dubito etiam ipsos maritos se nolle decipi, quibus solis permittendae sunt feminae ornari, secundum veniam, non secundum imperium". Suma teológica, II-II, q. 169, art. 2.

97 "Non tamen semper talis fucatio est cum peccato mortali, sed solum quando fit propter lasciviam, vel in Dei contemptum, in quibus casibus loquitur cyprianus. Sciendum tamen quod aliud est fingere pulchritudinem non habitam, et aliud est occultare turpitudinem ex aliqua causa, puta aegritudine vel aliquo hujusmodi. Hoc enim est licitum, quia secundum Apostolum, I ad cor., quae putamus ignobiliora esse membra corporis, his honorem abundantiorem circundamus". Ibidem.

98 Op. cit., p. 12

${ }^{99}$ Op. cit., pág. 6.

${ }^{100}$ CONCINA, op. cit., pág. 7.

101 "Fucata pigmentis facies, est Libidinis incentivum, et adulterii meditatio". Op. cit., pág. 6.

102 Justinianei de Stolatae Virginitatis Jure Lucubratio academica, Joann Lindani, Lugduni Batavorum, 1680, p. 98.

${ }^{103}$ BALDUINUS, op. cit., p. 648.

104 Op. cit., p. 27.
} 
contra el ornato superfluo e inverecundo de las mujeres"105. Balduinus preguntaba: ¿Qué se puede esperar de una cosa que está hecha de excremento de cocodrilo? ${ }^{106}$.

Aludían a las ficciones. Las cremas son malas si se pretende ocultar el color nativo ${ }^{107}$. Eran bastantes los que explicaban que las mujeres se pintan porque no se aceptan a sí mismas ${ }^{108}$. "Guarda tu cuerpo tal como fue hecho y no quieras pasar por otra. La mujer que se pinta con varios colores no es ella misma, sino la misma en otra" ${ }^{109}$. El cuerpo ya es de por sí bello ${ }^{110}, \mathrm{y}$ estos pigmentos que algunas mujeres usan en la cara pertenecen al ornato meretricio, y eso fue lo que hizo Judith, que simuló, ante Holofernes, ser una prostituta ${ }^{111}$. Pues, prosigue Balduinus, estas pinturas son de por sí ilícitas e impías; ante todo porque el hombre quiere reformar lo que creó Dios, como si su rostro no fuera lo suficientemente adecuado; las mujeres cometen una gran temeridad $^{112}$.

Tamburini, que estaba a favor del ornato femenino, nos decía, sin embargo. que bajo el nombre de ornato entendemos el interés de las mujeres hecho con cremas, el rizado de sus cabellos, la desnudez de sus pechos $<$ los escotes $>$, las joyas de oro y las gemas, las nuevas formas de vestir, especialmente cuando estas cosas se usan sobre lo que es costumbre o sobre el status de cada cual $^{113}$. Un resumen de este problema lo proporcionaba Alois Navarino: Facies fucata mulieris, facies Diaboli: La cara pintada de la mujer es la cara del Demonio ${ }^{114}$.

Eran peligrosos lo adornos en la cabeza, y varios cuentan el caso de Claudia, Virgen Vestal, que era realmente virgen, pero que era considerada mujer de mala vida porque se hacía peinar $^{115}$. Concina indicaba que Alejandro de Alés había escrito que las que se pintan o llevan pelucas, no deben ser admitidas a la Comunión, porque ésas pecan mortalmente ${ }^{116}$.

Estaba el tema nuevo de las depilaciones o afeytes, como escribían entonces. Gavarri, sigue la ley Palam del Digesto, y reitera que las que así se aliñan pecan por rameras y deshonestas ${ }^{117}$. Ezcaray era rotundo: San Cipriano había explicado "Que si las donzellas por no afeytarse han

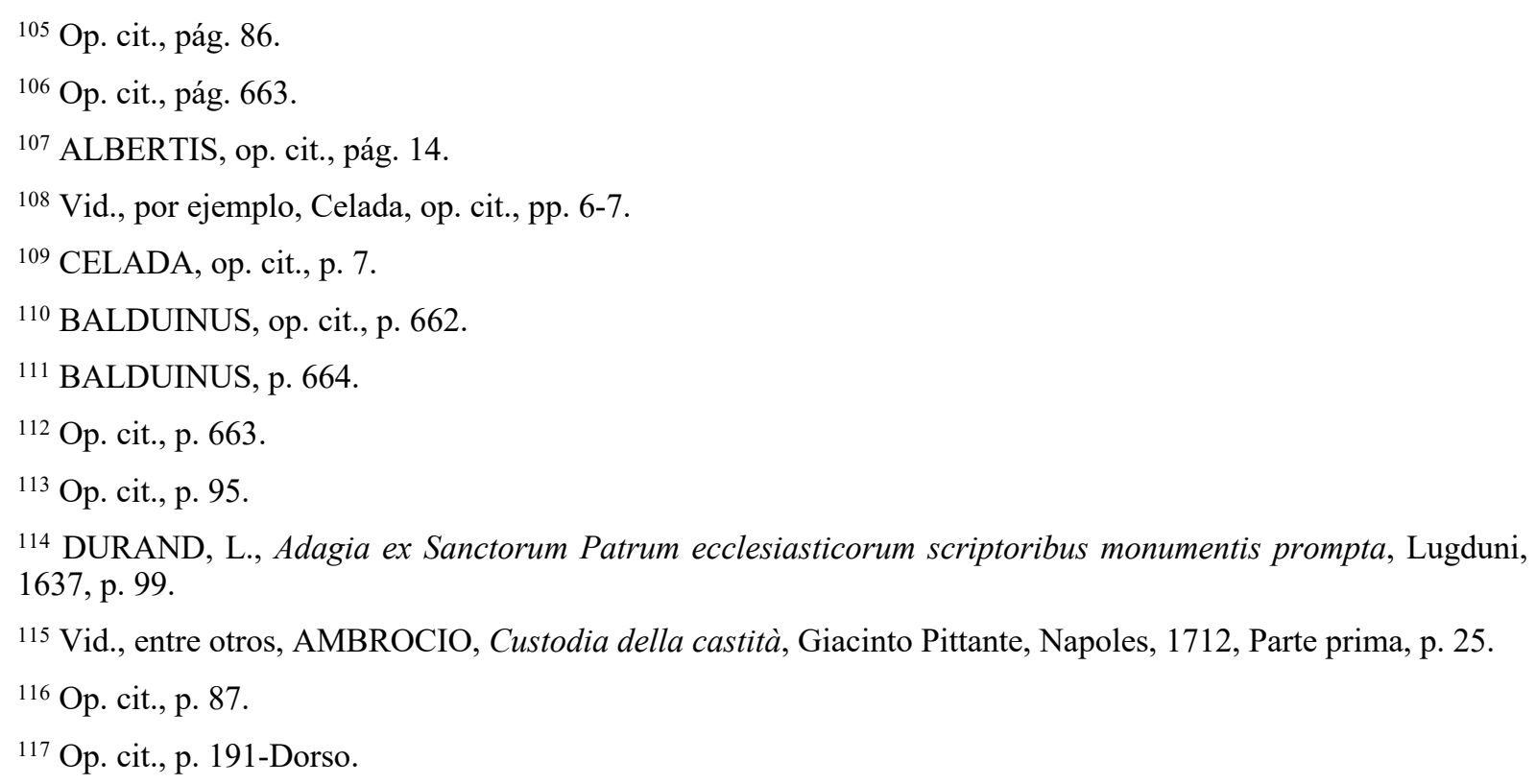


de perder casamiento, que lo pierdan y no se afeyten"118. San Jerónimo dijo en su carta a Demetrio: Se depilan los cabellos de la frente, se la despejan y exfolian, usan colorantes, tienen las manos cuidadas, sus vestidos sin una arruga, llevan unos zapatos dolorosos, y bajo el nombre de virginidad perecen estas mujeres que se venden ${ }^{119}$. Estas condenas alcanzaron también a los hombres, porque Galindo nos decía que "Los Españoles hacen como las mugeres, y se afeytan el rostro, dejándolo casi sin barba, como si fueran mugeres, lo qual es ignominia"120.

Torrecilla era más moderado en sus condena, porque explicaba que si el afeyte se hace simplemente por ostentar mayor hermosura, no excede los límites del pecado venial ${ }^{121}$. Y, prosiguiendo con este tema, añade que "Si lo dicho se hiciesse por causa justa, y como lo será en la donzella por casarse bien; y en la casada por dar gusto a su marido, o por encubrir algún defecto accidental del rostro, no sería pecado alguno" 122 . Amplía esta tesis y mantiene que si se depila según la costumbre de su patria, sin ninguna mala intención, esa mujer usa de su derecho ${ }^{123}$.

Según Tamburini, el cuerpo humano es más bello que los ornatos, ya que la naturaleza supera ampliamente al arte. Una mujer puede suponer que algunos hombres la desearán al verla, pero no está obligada bajo pena de pecado grave a dejar de adornarse, porque la malicia procede de ellos, no de la condición del tocado que lleva la mujer ${ }^{124}$. Este sector de teólogos sigue la línea de Cayetano, quien había explicado que si una mujer, por estas cosas, hace pecar a algunos, y esto es un evento remoto, no está obligada a dejar sus composturas ${ }^{125}$. Lessius se opuso al argumento basado en la pretendida ficción: "Si por usar cremas y otros pigmentos se produce una cierta ficción, como en esto no hay detrimento de nadie, esta culpa no es mortífera. Por lo demás, en esto no hay engaño, a no ser que la mujer pretenda que quienes la vean crean que ése es su color nativo. Quienes no lo hacen con este fin, sino sólo por parecer más bellas, abstrayendo la causa por la que se quiere esto, se puede decir que esto no conlleva pecado"126.

Lo que todos condenaban eran los excesos, fueran en los vestidos, fueran en las cremas. Albertis entiende que está mal descuidar la templanza o temperantia ${ }^{127}$, y por ello, quien se excede, comete un pecado venial ${ }^{128}$. Lessius hace una enumeración bastante completa de estos problemas cuando condena el 'afecto desordenado', esto es, el gran empeño o esfuerzo en estos

\footnotetext{
118 Op. cit., p. 54.

${ }^{119}$ CELADA, op. cit., p. 9.

${ }^{120}$ Op. cit., p. 50.

${ }^{121}$ Op. cit., p. 611.

122 Op. cit., p. 611.

123 TORRECILLA, op. cit., p. 611.

${ }^{124}$ Op. cit., pp. 95-96.

${ }^{125}$ Así, DE ALBERTIS, op. cit., p. 129.

126 Op. cit., p. 807.

127 Op. cit., p. 10.

${ }^{128}$ Op. cit., p. 13.
} 
temas, como hacen con frecuencia las mujeres, que dedican horas a ellos. Y así las mujeres jóvenes se vuelven frívolas. Además, esta falta de orden rara vez viene sola, porque casi siempre se hace por vanagloria, o por deleite, o por suscitar libido, o a todos estos vicios a la vez ${ }^{129}$.

En esta línea Balduinus entiende que gastan un tiempo y un dinero inútil en pintarse; esto es demencia, poner tanto trabajo en no hacer otra cosa que perderte a ti misma y a los demás ${ }^{130}$. Barbosa parece más ceñido a la realidad cuando expone que para qué tanto vestido precioso y tanto esfuerzo exquisito, y tanto dinero empleado en ellos. El marido ve cómo, por este lujo superfluo y ambicioso en los vestidos, la economía familiar peligra, por lo que las esposas que caen en estos esfuerzos tan inmoderados, se deben moderar y refrenar ${ }^{131}$.

Concina se pregunta si pecan los que venden estas cremas, o cartas para decir la suerte, o ídolos; y él mismo se contesta: "gravemente"132. Diana era muy de otra opinión, ya que él entendía que se podían vender cosas por las que sus compradores pecaran; lo que sucede cuando falta una causa razonable, es decir, una necesidad o una utilidad proporcionada; y así, Salas entiende también que se pueden vender cremas y vestidos a las mujeres aunque ellas fueran al adulterio $^{133}$.

\section{LOS ESCOTES}

Los autores modernos no hablaban de escotes, sino de escotados. Éste fue el tema moral que más tinta hizo gastar porque muchos no comprendían por qué, después de tantos siglos de ir vestidas las mujeres hasta la garganta, ahora habían de dejar un margen amplio entre el cuello y los pechos o bien, entre el cuello y parte de sus pechos: porque no siempre los escotes se detenían al inicio de las mamillae, sino que a veces descubrían parte de ellas. Las condenas fueron abundantes.

\section{a) En contra}

En este sentido, Gavarri escribía que las mujeres con aliños y afeites, si además van con escotados, están en perpetuo pecado mortal, "Porque si la hermosura natural de una muger sin afeyte alguno, tanto inflama los coraçones de los hombres; ¿que hace esa misma hermosura armada, con la desnudez y blancura de las carnes que muestran sus escotados? ${ }^{134}$ Y más, teniendo en cuenta que "Las galas, afeytes, etc. son gravemente provocativos a luxuria, sin los escotados, sino por sí solos"135. "Porque en verdad, si ay algún trage provocativo (dice un

\footnotetext{
${ }^{129}$ Op. cit., p. 805

${ }^{130}$ Op. cit., p. 645.

131 Op. cit., col. 235.

132 Op. cit., p. 315.

${ }^{133}$ Op. cit., Vol. 5, p. 139.

134 Op. cit., p. 194.

135 Op. cit., p. 192.
} 
Docto) es el de los escotados"136. "Dira alguno que dicho adorno no es malo de suyo, o quando mucho es pecado venial. Respondo, que adhuc sea así: por razón del efecto es pecado grave de escándalo activo"137.

Galindo y Ezcaray -aunque no son los únicos, ni mucho menos- se unen a Gavarri en estas condenas. Aquel nos dice que "Verdad que dichos trages profanos, y escotados deshonestos han sido siempre comúnmente tenidos por pecado grave" ${ }^{138}$, y añade que no escusa de pecado de escándalo la ignorancia, inadvertencia, duda, ni opinión probable ${ }^{139}$. Amplía esto último diciendo que no es aceptable mantener que "Es probable que el traxe de los escotados no provoca gravemente a la lujuria después de introducido; luego es probable que las mugeres lo puedan usar sin pecado mortal a vista de la opinión más verisímil $<$ sic $>$ de que provocan gravemente a la lujuria"" se dixo: "Dura cosa es que quiera este Padre que todos seamos santos" Y pregunto: ¿es quereros mal el desearos tanto bien?"141.

Comienzan a desarrollarse los argumentos. "Yo os quiero conceder, no teneis mala intención, ni mirais a nadie deshonestamente; ¿mas que os aprovechara esto si sois causa de que otros os miren, y torpemente se deleyten en la vista de vuestra escutada $<$ sic $>$ desnudez? ${ }^{142}$. ¿Y si hay buena intención? Galindo no admitía este tipo de buenas intenciones, y nos dice en un castellano de mala calidad: "La muger christiana, y honesta (dizen y enseñan los Maestros de la Virtud, y Religión christiana) ama su hermosura natural si ve puede ser lazo a los flacos para pecar, la debe encubrir, y aun si por modo licito puedala, debe afear, como de muchas santas Vírgenes se lee averlo hecho"143.

Algunas dicen que si la cara va destapada, los pechos ¿por qué no? "En la cara van los sentidos principales. La general razón no corre en traer las espaldas, ombros y pechos descubiertos ${ }^{144}$. Había una excusa que ya conocemos: ser costumbre, por lo que nadie debe asombrarse ante lo que es común. Galindo contesta que "No empero provoca mas el apetito sensual, y libidinoso, después de introducido, que antes"145. Las solteras pretextan que quieren casarse, o tomar estado: pero esto es una simple excusa ${ }^{146}$. Las casadas dicen que quieren agradar a sus maridos, y el omnipresente Galindo responde: "Digo ser vuestra escusa engañosa, porque si como dezís,

\footnotetext{
136 GALINDO, op. cit., p. 33.

${ }^{137}$ GALINDO, op. cit., p. 34.

138 GALINDO, op. cit., p. 8.

${ }^{139}$ GALINDO, p. cit., p. 54.

${ }^{140}$ GAVARRI, op. cit., p. 208.

${ }^{141}$ Op. cit., p. 322.

142 GALINDO, op. cit., p. 37.

143 Op. cit., pp. 34-35.

${ }^{144}$ GALINDO, op. cit., p. 60.

${ }^{145}$ Op. cit., pp. 61-62.

${ }^{146}$ GALINDO, op. cit., p. 46.
} 
vuestro aliño fuera en casa, delante de vuestros maridos: Mas vemos es al contrario, pues en vuestras casas y delante de ellos andáis desaliñadas, y haviendo de salir fuera, o recibir visita, gastais gran parte de la mañana, o toda, en componeros profanamente"147.

El modo correcto de vestir, según Galindo, ha de ser un "Juboncito con sus botones en el pecho, hasta la garganta" ${ }^{148}$. Alberto de Albertis había dado medidas más precisas: algunos dicen que los escotes han de tener dos dedos desde la raíz del cuello a las espaldas, ombros y pecho"; pero esto es pecado grave: ha de haber un solo dedo de escotado desde la raíz del cuello ${ }^{149}$. La añadidura de pecado grave para estas medidas consideradas tan excesivas no sé si son de Albertis o de Gavarri.

Todo lo que no sea esto es traje de prostitutas. "Todo traje meretricio es gravemente provocativo a luxuria; el trage profano que aquí condenamos (mayormente los excesivos escotados) es trage meretricio; luego es notablemente provocativo a luxuria"150. "Si un hombre extranjero aviendo leido que "Solo las Rameras pueden según la ley, traer jubones escotados", y encontrase en la calle tantas mugeres con jubones escotados, ¿no diría luego al punto: en esta tierra todas son mugeres publicas"? ${ }^{151}$. Es extraño este escándalo: Galindo se hace eco de una verdad bien sabida, que el dinero español se lo llevan los franceses con sus modas y abalorios ${ }^{152}$ : un tema sobre el que también insistió Gracián en otro contexto.

Las Autoridades han de intervenir ante estos abusos porque, como dice Galindo "De dichos daños, y su grave culpa, raras vezes escusa a las personas arriba dichas, mayormente a los Prelados, Reyes, ni Príncipes, la ignorancia vencible"153. Efectivamente, las autoridades intervinieron. "Alejandro VII exhorta tambien a todos los Obispos, y Prelados, en su bula despachada a 30. setiembre de 1656, prohíban dichos escotados con censuras ... excomunion latae sententiae, como asi lo refiere el Edicto que publicó el Sr. Arzobispo de Zaragoça Gamboa el año 1671, en el que los prohibio tambien con excomunión latae sententiae"154. Jaime de Corella informa lo mismo, a saber, que "El Ilmo. Gamboa, Arzobispo de Zaragoça, mando con esta pena, que no se admitieran a los sacramentos a las mugeres que llegassen con escotados profanos; y con mucha razón: porque un trage indecente es indicio de una vida relaxada"155. Gavarri insiste: "Que las tales mugeres que usan de los trages escotados, son indignas de la Sagrada Comunión, y aunque los llevasen con buena intención"156. Galindo ataca en varios

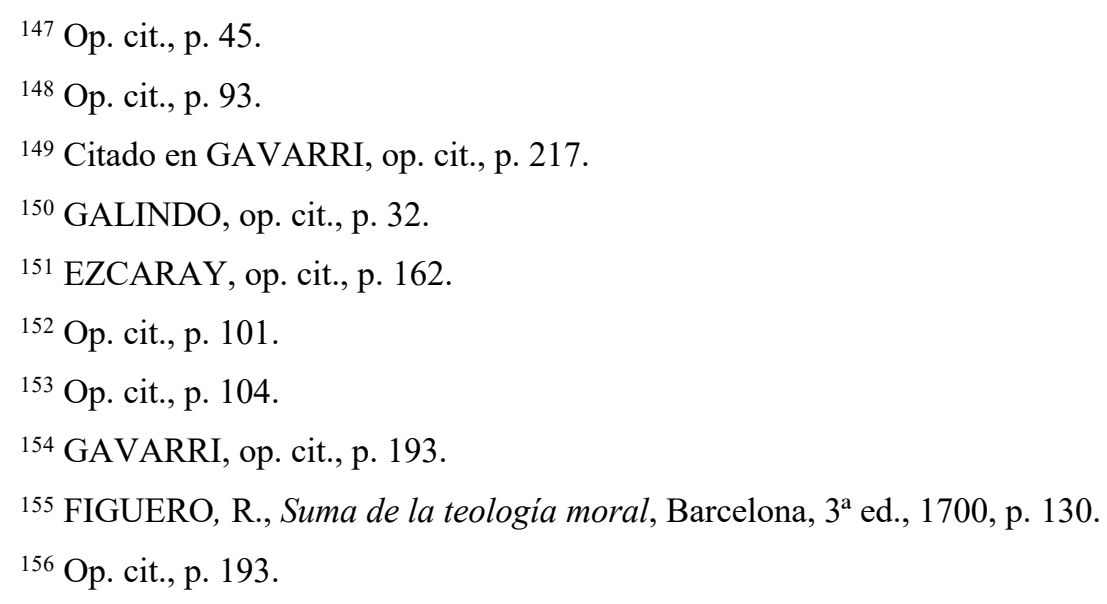


ocasiones a Sicardo sin nombrarlo expresamente, porque Sicardo admitía los "escotados moderados" 157 . No tenían en cuenta lo que había indicado Bonfini, a saber, la poca eficacia de la razón para mover a la voluntad, de modo que las leyes hacen el ridículo ${ }^{158}$.

\section{b) A favor}

A pesar de lo alegado en otros momentos, el mismo Gavarri declara que los escotes eran costumbre amplia: "Los escotados, por si solos, que usan oy las mas de las mugeres, y especialmente casi todas las señoras, no siendo de mucha edad... ${ }^{159}$. Si negaban los sacramentos a la mayor parte de las mujeres, y especialmente a las más señoras, parece que incurrían en una actitud poco sensata y poco pastoral.

Torrecilla, muy activo en este tema, escribía que "Respondo tamen: que no sería pecado mortal lo dicho, con tal que se haga según la costumbre de la patria, y sin alguna mala intención"160. Cita a favor de esta tesis a Santo Tomás, Cayetano, Navarro, Lessius y muchos más. "Dixe al principio: "Donde esta recebida la tal costumbre", porque juzgo seria pecado mortal al introducirla de nuevo: como bien, con Cayetano, Funo, Navarro, y otros, lo tienen dicho Lessio, Azor y Bonacina citados" $" 161$.

Lessius fue bastante claro en defensa de este argumento: "Desnudando el pecho, como sostienen Cayetano, Fumus y Navarro, especialmente donde hay esta costumbre: pues esa parte se considera honesta, y ni la naturaleza ni el pudor humano exigen que se cubra totalmente"162. Torrecilla insiste: "Imo, ay muchos que son de sentir: que donde esto está en uso, es menos provocativo que lo contrario: y esto lo conforman los que vienen de aquellas partes de las Indias, donde las mugeres andan todo el cuerpo desnudo; los quales dizen las provocan menos, que el verlas engalanadas cuando vuelven a España. Y en sentir de otros, más provocan las mujeres tapadas de medio ojo, que las que andan con la cara descubierta; y assi dicho libro no disminuye la probabilidad de la opinión contraria, ni fuera difícil a los Autores de nuestra opinión satisfacer en individuos a los fundamentos, aunque graves, y muy eruditos, del dicho libro". ${ }^{163}$

Este libro a que se refiere Torrecilla fue un manuscrito enviado por el Arzobispado de Santiago de Compostela al Rey para que prohibiera los escotes, y el Rey -que no se debía considerar dotado para dictar doctrina moral- remitió este libro a la Santa Inquisición, que reunió a un Consejo de Calificadores. Pero es mejor dejar hablar a Torrecilla. "Y de este sentir fueron la mayor parte de los Calificadores, en una Junta, que se tuvo sobre el punto, de orden de su

\footnotetext{
${ }^{157}$ GALINDO, pp. 71 y 84.

158 VACKLEIS, C., Symposion trimeron, de virginitate et pudicitia coniugali dialogo III, Francofurti, 1621, pP. 38.

159 Op. cit., p. 92.

160 Op. cit., p. 612.

${ }^{161}$ Op. cit., p. 612.

162 Op. cit., p. 807.

163 Op. cit., p. 612.
} 
Magestad; que instaba el arzobispo de Santiago, sobre que mandasse prohibir los escotados en su Reyno, poniéndoselo en conciencia, y remitiendo a su Magestad para dicho fin un libro de a quartilla, que compuso para la materia el Reverendissimo y doctissimo Padre Tirso, de la Compañía de Jesus (oy meritissimo General de dicha Sagrada Religion). Su Magestad lo remitio al Consejo de la Santa Inquisicion, para que le informasse de su sentir, en orden a ser pecado mortal, o no dicho caso de los escotados. Y los más de los Calificadores, que se hallaron en dicha Junta, firmaron que no: y que el tal libro (aunque doctissimo) no disimula la posibilidad de la opinión contraria"164.

Torrecilla, que entiende que ésta era costumbre extendida, y que esa parte del cuerpo se juzga honesta, entendía que, bajo estas circunstancias, toda mujer usa de su derecho llevando escote $^{165}$. "Por lo qual, dize Lessius: que aunque la tal muger juzgue, que han de pecar algunos, no esta obligada debajo de pecado mortal a dexar el tal ornato. Y la razón es porque el tal ornato, solo remotamente provoca al mal"166. Y, prosigue este autor, la tal ocasión para la lascivia una vez que se ha sentado que el escote es solamente un peligro remoto- más viene de la malicia de tal amante que de ella. Reitera que tal mujer usa de su derecho y libertad" ${ }^{167}$. Y "Lo otro, porque al adornarse las mugeres para ser hermosas y ser alabadas, y ser tenidas por tales, no es pecado mortal: porque esto por sí no contiene grave desorden, sino solo una cierta jactancia y vanagloria. Ni el exceso en este ornato es per se pecado mortal, como con Santo Tomás, Cayetano y otros, lo tiene el sobredicho Lessius"168. "De lo dicho se sigue, como se debe comportar el Confessor en dicha materia con las mujeres escotadas: porque aunque todas deben ser exhortadas a moderar el dicho ornato, con todo esso, si no quisiera dexarle alguna, no por ello se le debe negar la absolución"169.

Torrecilla parece un hombre humilde que no quiere llevar la contraria a teólogos esclarecidos. Aunque él advierte su intención final en las últimas lineas de este capítulo, cuando indica que "Advierto empero con todos los Doctores que peca mortalmente la muger, que sin justa causa muestra las partes pudendas, o las cubren con alguna gassa, o tela, de la tal suerte diáfana, y transparente, que puedan ser vistas de otros ... como bien han dicho Lessio, Bonacina y Azor. $\mathrm{Y}$ assi las que usansse de semejante telilla, diáfana y tenue, no pueden, ni deben ser absueltas hasta que dexen el tal mal uso; o por mejor decir, el tal depravado, escandalosissimo e infernal abuso" $" 170$.

\footnotetext{
${ }^{164}$ Op. cit., p. 612.

${ }^{165}$ Op. cit., p. 612.

166 TORRECILLA, op. cit., p. 612.

167 TORRECILLA, op. cit., p. 250.

168 TORRECILLA, op. cit., p. 612.

169 Op. cit., p. 613.

170 Op. cit., p. 613.
} 